\title{
Case report. Infarcering van een testis bij een patiënt met sikkelcelanemie
}

\author{
A. J. W. Beulens ${ }^{1}$ (I) $\cdot$ M. B. G Kuenen ${ }^{2}$ L. S. F. Yo ${ }^{2}$ E. L. Koldewijn ${ }^{2}$
}

Published online: 14 June 2017

(C) The Author(s) 2017. This article is an open access publication.

Samenvatting Van alle patiënten die met subacute pijnklachten aan het scrotum gezien worden op de Spoedeisende Hulp (SEH) wordt slechts een klein aantal gediagnosticeerd met een torsio testis. Veelal blijkt na lichamelijk onderzoek en echografie met kleurendoppler van het scrotum iets anders aan de hand te zijn, in de meeste gevallen epididymo-orchitis. Bij sommige patiënten blijkt er een andere, zeldzamere, oorzaak aan de klachten ten grondslag te liggen. Wij beschrijven de casus van een 20 -jarige man van Haitiaanse afkomst met een pijnlijke linkertestis op basis van een infarcering van zijn testis bij sikkelcelanemie.

Trefwoorden torsio testis - sikkelcelanemie $\cdot$ infarcering • sikkelcelcrisis

\section{Case report. Infarction of a testis in a patient suffering from sickle cell anaemia}

Abstract Of all patients who visit the Emergency Room (ER) with scrotal pain, only a small number is diagnosed with testicular torsion. After physical examination and ultrasound with colour doppler of the scrotum the majority of these patients are diagnosed with another condition, in most cases an epididymo-orchitis. However, in some cases there a less common cause for the pain is found. We present the case of a 20-year-old Haitian male in our ER, suffer-

\footnotetext{
A. J. W. Beulens

ajwbeulens@gmail.com

Maastricht University, Maastricht, Nederland

2 afdeling Urologie, Catharina Ziekenhuis, Eindhoven, Nederland
}

ing from an acute painful left testicle, caused by testicular infarction based on sickle cell anaemia.

Keywords testicular torsion - sickle cell anaemia . infarction $\cdot$ sickle cell crises

\section{Introductie}

Acute scrotale pijn in de leeftijd van 0-25 jaar kan diverse oorzaken hebben. Veel voorkomende oorzaken zijn torsio testis en torsio appendix testis. Acute scrotale pijn komt jaarlijks voor bij ongeveer 1 op de 4000 mannen in deze leeftijdscategorie. Ook een epididymo-orchitis of trauma aan het scrotum kan de oorzaak zijn van deze klacht [1]. In zeldzame gevallen is acute scrotale pijn het gevolg van een sikkelcelcrisis, zoals bij de patiënt die wordt beschreven in deze casus.

\section{Casus}

Een 20-jarige man van Haïtiaanse afkomst werd in de avonduren gezien op de Spoedeisende Hulp (SEH), met reeds drie dagen bestaande acuut ontstane pijn in de linkertestis en zwelling van het linkerhemiscrotum. Er was tevens sprake van een lichte zwelling van de penis. Patiënt had geen last van misselijkheid of braken. In de voorgeschiedenis had hij meerdere vaso-occlusieve crises bij een homozygote sikkelcelanemie met een hoog HbSS van $92 \%$. Bij lichamelijk onderzoek waren beide testes laagscrotaal palpabel en werd een zwelling gezien van de linkertestis en de epididymis, die fors pijnlijk was. De funiculus spermaticus was volledig soepel en niet drukpijnlijk. De rechtertestis vertoonde geen bijzonderheden. 


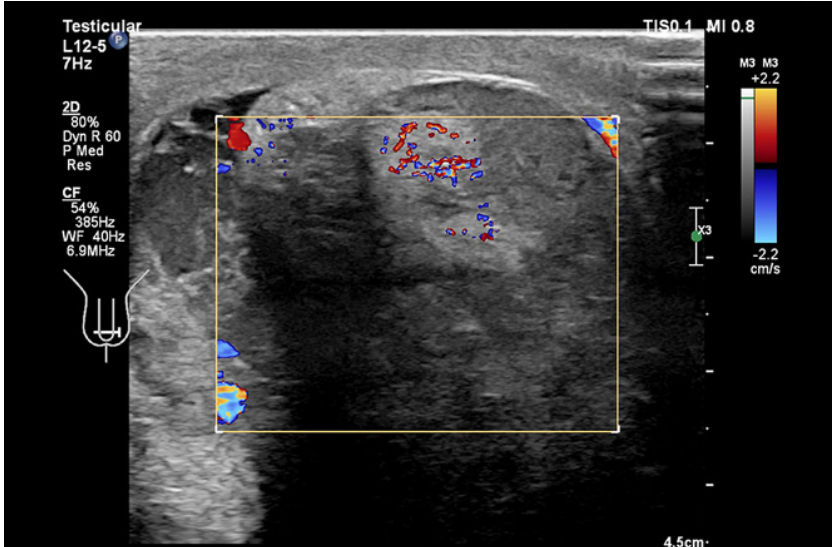

Figuur 1 Echografische afbeelding van de linkertestis bij opname, met een niet-homogeen aspect van de linkertestis, met een geringe, enigszins vlekkerige flow.

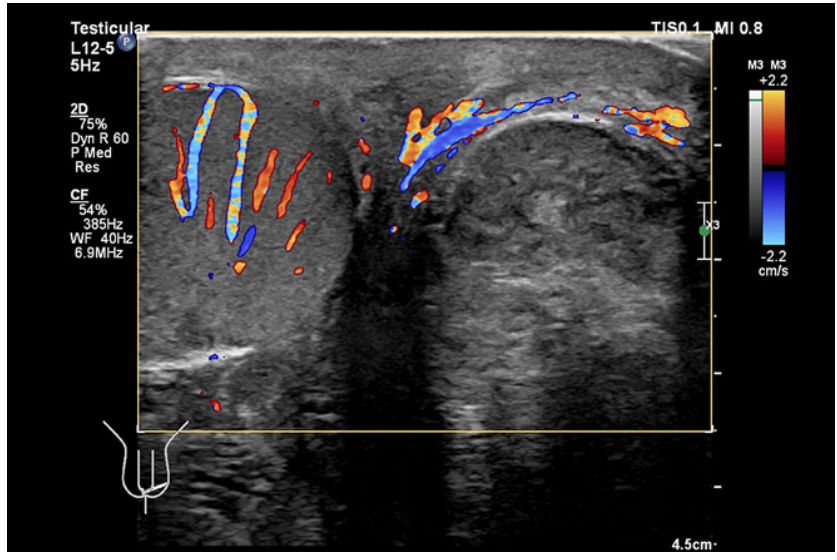

Figuur 2 Echografische afbeelding van de linkertestis (rechts) en rechtertestis (links) de ochtend na opname, zonder flow in de linkertestis en een normale flow in de rechtertestis.

Bij de echografie van het scrotum met kleurendoppler werd een fors gezwollen, niet-homogeen aspect van de linkertestis gezien, met een geringe, enigszins vlekkigerige flow, een vergrote epididymis en een spoortje vocht (fig. 1). De rechtertestis was echografisch niet afwijkend. $\mathrm{Bij}$ het laboratoriumonderzoek werden, behoudens een verhoogd leukocytengehalte van 17,8 leukocyten/nl (normaal 4,0-10,0 leukocyten/nl), een verhoogd LD-gehalte van $258 \mathrm{U} / \mathrm{L}$ (normaal < $248 \mathrm{U} / \mathrm{l}$ ) en een verhoogd CRPgehalte van $32 \mathrm{mg} / \mathrm{l}$ (normaal $<6,0 \mathrm{mg} / \mathrm{l}$ ) geen bijzonderheden gevonden. In het urinesediment was geen sprake van leukocyturie of erytrocyturie; het nitriet was negatief.

Op basis van deze bevindingen werd de patiënt opgenomen ter observatie, en werd adequate pijnstilling gestart. Ook werd gestart met ofloxacine vanwege verdenking op een orchitis. De volgende dag werd de echo herhaald wegens aanhoudende pijnklachten. Er werd nu geen enkele flow gezien (fig. 2). Hierop werd besloten het scrotum te exploreren.

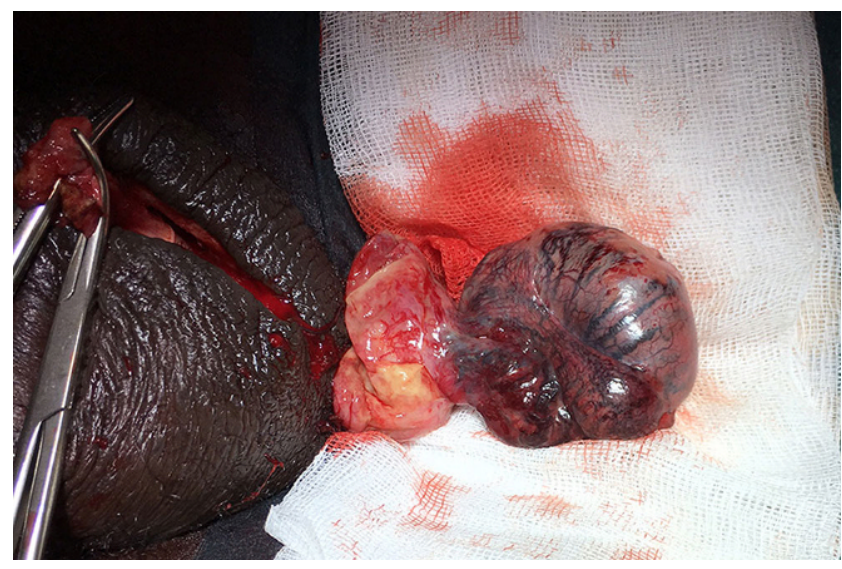

Figuur 3 Foto van de testis direct na orchidectomie, met zwarte verkleuring van de testis en epididymis en de funiculus spermaticus, midden in beeld, tegen het lichaam, roze en vitaal.

Peroperatief werd een zwartverkleurde testis links gezien, met een volstrekt slanke en vitale funiculus spermaticus tot aan de testis (fig. 3). Er werd geen draaiing gezien. De testis werd in warme, natte gazen gewikkeld en de rechtertestis werd gefixeerd. Na 20 minuten was de linkertestis niet bijgekleurd en werd besloten deze te verwijderen.

Uit pathologisch onderzoek bleek er sprake te zijn van hemorragisch geïnfarceerd testisweefsel, met uitgebreide necrose van de testisbuizen en bloeding in het interstitium. Vitale gedeelten van de testisbuizen toonden een normale spermatogenese. De epididymis had geen kenmerkende afwijkingen. In de epididymis en in de funiculus spermaticus werden gestuwde bloedvaten met langgerekte erytrocyten gevonden, die morfologisch bij sikkelcelanemie passen. De diagnose was: een linkertestis met hemorragische infarcering bij sikkelcelanemie (fig. 4). Het postoperatief beloop was ongecompliceerd en de patiënt werd in goede klinische conditie ontslagen. Bij poliklinische controle bleek sprake te zijn van een georganiseerd hematoom in het linkerhemiscrotum. Hierop werd besloten de ofloxacine te continueren en een expectatief beleid te voeren. Bij latere poliklinische controle was de zwelling beduidend minder geworden en waren alle klachten verdwenen.

\section{Bespreking}

Bij onze patiënt werd, op basis van het klinisch beeld, het langere bestaan van de klachten en het lichamelijk en aanvullend onderzoek, eerst gedacht aan een orchitis, hoewel het echografisch beeld aanvankelijk enigszins atypisch was. Aangezien de eerste echo (fig. 1) flow toonde, is niet direct overgegaan tot exploratie van het scrotum, maar wel bij aanhoudende klachten en na een tweede echo, waarop geen flow aangetoond kon worden (fig. 2). Bij lichamelijk onderzoek werd een slanke en niet-drukpijnlijke funiculus 


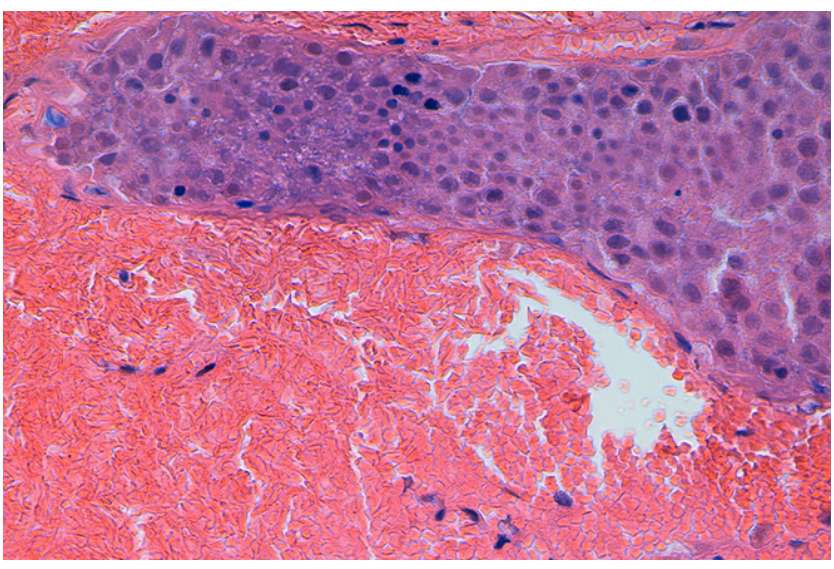

Figuur 4 Testisweefsel, hemorragisch geïnfarceerd met uitgebreide necrose van de testisbuizen en bloeding in het interstitium. De langgerekte erytrocyten passen morfologisch bij sikkelcelanemie.

spermaticus gevonden. Ook bij chirurgische exploratie leek de funiculus spermaticus niet afwijkend. Bij pathologisch onderzoek werd echter wel infarcering van de testis gezien. De bevindingen wezen op gegeneraliseerde occlusie van de testis op basis van een crisis bij een patiënt die bekend was met homozygote sikkelcelanemie.

Testiculaire infarcering wordt in de kliniek voornamelijk gezien als gevolg van een torsio testis, en slechts in zeer zeldzame gevallen als gevolg van sikkelcelanemie; in de literatuur zijn daarvan minder dan 20 casus beschreven. Deze betreffen met name segmentale infarcering bij patiënten met heterozygote aanleg voor sikkelcelanemie. Bruno et al. beschreven in hun review testiculaire occlusie als een van de complicaties bij sikkelcelanemie [2]. Zij refereerden aan drie patiënten van verschillende leeftijd, bij wie de klachten uiteenliepen van langer bestaande scrotale zwelling tot een acuut scrotum. Geen van de mannen reageerde op de in eerste instantie ingezette antibiotische behandeling. Bij pathologisch onderzoek na radicale orchidectomie bleek bij alle drie segmentale infarcering van de testis te bestaan [3-6]. Andere casus betreffen patiënten die zich met (sub)acute klachten presenteerden na één tot drie dagen, bij wie segmentale testiculaire infarcering werd vastgesteld en bij wie partiële orchidectomie was uitgevoerd [7, 8].

Naast de standaardbehandeling bij een vaso-occlusieve crisis, bestaande uit ruime vochtintake, pijnstilling en, in ernstige gevallen, wisseltransfusies, zijn er bij een testiculaire infarcering door sikkelcelanemie geen curatieve opties. Bij segmentale infarcering is partiële orchidectomie moge- lijk. In alle overige gevallen is een radicale orchidectomie de enige oplossing.

\section{Conclusie}

Bij patiënten met een voorgeschiedenis van sikkelcelanemie, die zich met een acuut scrotum presenteren, is het aan te raden snel over te gaan tot chirurgische exploratie van het scrotum. In sommige gevallen is de testis dan nog ten dele te behouden. Wanneer de testis niet meer vitaal is, kan, net als bij de patiënt in deze casus, overgegaan worden tot een radicale orchidectomie.

Open Access This article is distributed under the terms of the Creative Commons Attribution 4.0 International License (http:// creativecommons.org/licenses/by/4.0/), which permits unrestricted use, distribution, and reproduction in any medium, provided you give appropriate credit to the original author(s) and the source, provide a link to the Creative Commons license, and indicate if changes were made.

\section{Literatuur}

1. Hendrikx AJM, Vries JDM de, Debruyne FMJ. Differentiële diagnostiek en therapie bij acute aandoeningen van het scrotum. Ned Tijdschr Geneeskd. 1988;132:1142-5.

2. Bruno D, Wigfall DR, Zimmerman SA, Rosoff PM, Wiener JS. Genitourinary complications of sickle cell disease. J Urol. 2001;166(3):803-11.

3. Holmes NM, Kane CJ. Testicular infarction associated with sickle cell disease. J Urol. 1998;160:30.

4. Gofrit ON, Rund D, Shapiro A. Segmental testicular infarction due to sickle cell disease. J Urol. 1998;160(3part1):835.

5. Urwin GH, Kehoe N, Dundas S. Testicular infarction in a patient with sickle cell trait. Br J Urol. 1986;58:340.

6. Maomi L, Fogarty J, Whitney KD, Stone P. Repeated testicular infarction in a patient with sickle cell disease: a possible mechanism for testicular failure. Urology. 2003;62(3):551.

7. Debeck C, Ghasemain R. Acute segmental testicular infarction. Internat. J Urol. 2006;13:651-2.

8. Mueller FE. Segmentaler hodeninfarkt bei sichelzellenanämie. Urologe. 2014;53(5):725-7.

A.J.W. Beulens geneeskundestudent

drs. M.B.G Kuenen uroloog

drs. L.S.F. Yo radioloog

dr. E.L. Koldewijn uroloog 